\title{
Evaluation of Chilli Genotypes for Yield Attributing and Incidence of Leaf Curl and White Fly Traits in Coastal Maharashtra, India
}

\author{
N. Yatagiri ${ }^{1}$, R.K. Telugu ${ }^{2 *}$, M. Shafiqurrahaman ${ }^{3}$ and P.B. Sanap ${ }^{1}$ \\ ${ }^{1}$ Department of Horticulture, Dr. Balasaheb Sawant Konkan Krishi Vidyapeet, \\ Dapoli - 415712, Maharashtra, India \\ ${ }^{2}$ Department of Vegetable Science, Chaudhary Charan Singh Haryana Agricultural University, \\ Hisar-125004, Haryana, India \\ ${ }^{3}$ Department of Genetics and Plant Breeding, Chaudhary Charan Singh Haryana Agricultural \\ University, Hisar-125004, Haryana, India \\ *Corresponding author
}

\section{A B S T R A C T}

\begin{tabular}{|c|}
\hline Keywords \\
\hline $\begin{array}{l}\text { Chilli, yield, Leaf } \\
\text { curl, White fly, } \\
\text { Genotype. }\end{array}$ \\
\hline Article Info \\
\hline $\begin{array}{l}\text { Accepted: } \\
28 \text { August } 2017 \\
\text { Available Online: } \\
\text { 10 September } 2017\end{array}$ \\
\hline
\end{tabular}

Nineteen chilli genotypes were evaluated for yield and yield components during rabi season at Vegetable Improvement Scheme, Central Experimental Station, Wakavali. Among nineteen genotypes Pant- $\mathrm{C}_{3}$ exhibited significantly superior performance with the production of highest green fruit yield per plant $(555.63 \mathrm{~g})$, green fruit yield per hectare (19.72t), maximum pickings (4.95) over rest of genotypes. As regards to other yield components, genotype Pashighat-7 took maximum days to first harvesting while genotype Karvir Local recorded maximum green fruit weight $(6.05 \mathrm{~g})$, fruit length $(12.40 \mathrm{~cm})$, minimum days to first fruit harvest (74.50) and maximum leaf curl disease incidence in the genotype Pashighat-7 (18.90\%), minimum in the genotype 'Pant- $C_{3}$ ' $(5.3 \%)$ and maximum white fly incidence in the genotype 'Pashighat-7' $(1.38 \%)$ and minimum incidence in the genotypes 'Pant- $\mathrm{C}_{3}$ ' $(0.35 \%)$. Overall performance of the genotypes revealed that the genotype Pant- $\mathrm{C}_{3}$ is the superior genotype for most of the traits studied among the nineteen chilli genotypes.

\section{Introduction}

Chilli (Capsicum annum L.) is one of the most important commercial crops of India. In India, only two species viz., Capsicum annum L. and Capsicum frutescence L. are well known and most of the cultivated varieties belong to Capsicum annum. This cultivated species has its unique place in the diet as a vegetable cum spice crop. Chilli is an indispensable spice due to its pungency, taste, appealing colour and flavor. It is the second largest commodity after black pepper (Piper nigrum L.) in the international spice trade. Capsicum spp. contain a range of essential nutrients and bioactive compounds which are known to exhibit antioxidant, antimicrobial, antiviral, anti-inflammatory and anticancer properties (Khan et al., 2014). In India, it is an important ingredient in daily cuisine and is also used in the preparation of pickles, chutneys, sauces etc. The pungency in chilli is due to a crystalline, acrid, volatile alkaloid, capsaicin present in placenta and pericarp of 
the fruit which has high diverse prophylactic and therapeutic uses in Allopathic and Ayurvedic medicine value. It is also a good source of oleoresin which has varied uses in processed food beverage industries and got high export potential. The natural colour extracts of chilli are also finding increased value in place of artificial colours in the food items especially in developed countries. India has greater potential to increase the chilli production in order to promote exports which may help in price stabilization of the commodity within the country, particularly during the peak periods of production. Higher yield and host plant resistance genes have to be identified in the gene pool existing as landraces, wild and semi-domesticated relatives of cultivated species for exploitation in breeding programmes (Sharma and Ortiz, 2002). The most vital production constrains in chilli attacked by several insect and non-insect pests where, thrips, Scirtothrips dorsalis Hood, yellow mite, Polyphagotarsonemus latus (Bank) and fruit borer complex, Helicoverpa armigera (Hübner) and Spodoptera litura Fab. (Kavitha et al., 2006). The low productivity is often attributed to many limiting factors such as lack of superior genotypes / improved cultivars for use in breeding programme to develop potential hybrids, severe incidence of insect pests (thrips, mites and borers) and diseases (anthracnose, leaf spots and viral diseases) resulting in tremendous reduction in yield and quality. Further, the high variability present in the crop has so far not been fully exploited in the crop improvement programme. Chilli genotypes are found with varying characters of diverse types. Hence, there is need to evaluate chilli genotypes under this condition for excellent quality, yield and growth performance and resistant to biotic and a biotic stress. In view of this, present investigation was undertaken in chilli to gather information on yield and yield components and identification of suitable chilli genotypes for coastal Maharashtra conditions.

\section{Materials and Methods}

The experiment was conducted at the Vegetable Improvement scheme, Central Experimental Station, Wakawali, Dr. Balasaheb Sawant Kankan Krishi Vidyapeeth, Dapoli during the Rabi season. The soil of the experimental field is lateritic in nature and sandy loam in texture. It was acidic in reaction having $\mathrm{pH}$ 6.4. The experiment was laid out in Randomized Block Design (RBD) with two replications with spacing of $65 \times 45 \mathrm{~cm}$ row to row and plant to plant. All the recommended package of practice and plant protection measure were followed to raise the crop healthy. Observations were made on randomly selected five plants from each genotypes and replication. Nineteen chilli genotypes (Figure 1) namely $\mathrm{T}_{1}$ Konkan Kirti, T 2 - LCA-206, T 3 - LCA-334, $\mathrm{T}_{4}$ - Arka Supriya, $\mathrm{T}_{5}-$ Jayanti, $\mathrm{T}_{6}-$ Pant- $_{3}$, $\mathrm{T}_{7}$ - ACSS-9818, $\mathrm{T}_{8}$ - Phule Sai, $\mathrm{T}_{9}$ - Pusa Jwala, $\mathrm{T}_{10}-\mathrm{DPL}_{1} \mathrm{C}_{1}, \mathrm{~T}_{11}-\mathrm{DPL}_{2} \mathrm{C}_{2}, \mathrm{~T}_{12}$ - DPL$\mathrm{C}_{4}, \mathrm{~T}_{13}-\mathrm{DPL}_{-} \mathrm{C}_{5}, \mathrm{~T}_{14}$ - Pashighat-1, $\mathrm{T}_{15}$ Pashighat-2, $\mathrm{T}_{16}$ - Pashighat-5, $\mathrm{T}_{17}$ Pashighat-7, $\mathrm{T}_{18}$ - Karvir Local, $\mathrm{T}_{19}$ - Pachora Local-1. A basal dose of $150 \mathrm{~kg} \mathrm{~N}, 80 \mathrm{~kg}$ $\mathrm{P}_{2} \mathrm{O}_{5}$ and $100 \mathrm{~kg} \mathrm{~K} 2 \mathrm{O} /$ ha was applied. Half of the nitrogen and full amount of the phosphorus and potash were given as basal dose at the time of transplanting, remaining half quantity of nitrogen was applied in two split doses at 30 days and 60 days after transplanting. The healthy seedlings of uniform growth and healthy were selected for planting. Light irrigation was given before uprooting seedlings from the nursery beds so that minimum damage may occur to the roots of seedling. Appropriate agronomic practices were followed to raise a good crop. Various observations were recorded on yield attributing parameters viz., Fruit length $(\mathrm{cm})$ [upto $4 \mathrm{~cm}$ short, $4-6 \mathrm{~cm}$ medium $\&$ above 6 
very long length], Fruit diameter (cm), Days to first harvest, Harvesting span, Number of picking per plant, Average fruit weight (g), Number of fruits per plant, Fruit yield per plant (g), Fruit yield t/ha, Disease and Pest Incidence viz., Incidence of Leaf curl/plant $(\%)$, Incidence of white fly/leaf (\%). The recorded data was statistically analyzed by ANOVA method given by Panse and Sukhatme (1989).

\section{Results and Discussion}

\section{Yield attributing parameters}

\section{Fruit length (cm)}

The fruit length recorded to be up to $4 \mathrm{~cm}$ short, up to $4-6 \mathrm{~cm}$ medium, above $6 \mathrm{~cm}$ very long length (Table 1). The fruit length was varied from $4.36 \mathrm{~cm}$ to $12.40 \mathrm{~cm}$ with a mean value of $8.38 \mathrm{~cm}$. All the genotypes were observed in 'long length' except genotypes in the genotypes $\mathrm{T}_{10}$ 'DPL- $\mathrm{C}_{1}$ ' and $\mathrm{T}_{14}$ 'Pashighat-1' which showed medium length. The maximum fruit length was observed in the genotype $\mathrm{T}_{18}$ 'Karvi Local' followed by $\mathrm{T}_{2}$ 'LCA-206' and minimum fruit length was observed in the genotype $\mathrm{T}_{17}$ 'Pashighat-7' and followed by $\mathrm{T}_{14}$ 'Pashighat-1'. $\mathrm{T}_{18}$ 'Karvir Local' was significantly superior treatment as compared to all other treatments.

Variation of the fruit length in different genotypes under study could be attributed to the genotypes characteristics, difference in the genetic makeup of genotypes. The similar variation in fruit length was observed by Ukkund et al., (2007), Tembhurne et al., (2008), Thul et al., (2009) and Vijaya et al., (2014).

\section{Fruit diameter $(\mathrm{cm})$}

The fruit diameter ranged from $0.66 \mathrm{~cm}$ to $1.00 \mathrm{~cm}$ into the average value of $0.83 \mathrm{~cm}$. Maximum fruit diameter $(1.00 \mathrm{~cm})$ was recorded in the genotype $\mathrm{T}_{14}$ 'Pashighat-1' followed by $\mathrm{T}_{10}$ 'DPL- $\mathrm{C}_{1}$ ' $(0.95 \mathrm{~cm})$ and minimum fruit diameter in the genotype $\mathrm{T}_{15}$ 'Pashighat-2' $(0.66 \mathrm{~cm})$, followed by $\mathrm{T}_{2}$ 'LCA-206' (0.73 cm). T 14 'Pashighat-14' was significantly superior treatment compared to all other treatments except $T_{3}, T_{4}, T_{10}, T_{13} \&$ $\mathrm{T}_{18}$ which were statistically at per.

Such variation of the fruit diameter different genotypes due to genetics make up of genotypes.

The similar variation in fruit diameter was observed by Ukkund et al., (2007), Tembhurne et al., (2008), Chattopadhyay (2011) and Thul et al., (2009).

\section{Days to first harvest}

From the data (Table 1) it is clear that genotype $\mathrm{T}_{18}$ 'Karvir Local' (74.50 days) took less no of days to first picking followed by $\mathrm{T}_{14}$ 'Pashighat-1' (78.50 days) and late picking was observed in the genotype $T_{17}$ 'Pashighat-7' (116.50 days) followed by $\mathrm{T}_{19}$ 'Pachora Local' (109.50 days) at first harvest. The treatment $\mathrm{T}_{18}$ 'Karvir Local' was significantly superior in earliness in comparison to other treatments.

Numbers of days to first harvest determine earliness of genotypes. It is obvious that the genotype producing early yield is considered best because, the early produce receives higher price in market. It is therefore necessary to give due consideration for this trait while selection of genotypes for earliness yield.

The variation among different genotypes may be due to the genetic influence of genotypes, effect of low concentration of hormones and low environmental effects. The results are in conformity with those of Sharma et al., (2010), Manju and Sree lathakumary (2002) and Shiva et al., (2013). 


\section{Days to last harvest}

The genotype $\mathrm{T}_{15}$ 'Pashighat-2' showed lowest number of days (115.90) to late picking, followed by $\mathrm{T}_{5}$ 'Jayanti' (122.10) and late picking was observed in the $T_{17}$ 'Pashighat-7' (166.00) followed by $\mathrm{T}_{19}$ 'Pachora Local' (162.50) at last harvest. The treatment $\mathrm{T}_{15}$ was significantly superior in earliness as compared to all other treatments except $\mathrm{T}_{5}, \mathrm{~T}_{14}, \mathrm{~T}_{16}$ and $\mathrm{T}_{18}$ which were statistically at par.

The variation of days to last harvest was mostly due to GCV of genotypes and low effect of environment. These results are in agreement with those of Sharma et al., (2010), Manju and Sreelathakumary (2002) and Shiva et al., (2013).

\section{Harvesting span}

Harvesting duration is the important character especially in vegetable crops, which are consumed at immature tender stage. The more harvesting span is considered as favorable character and given due consideration during selection.

The genotype $\mathrm{T}_{15}$ 'Pashighat-2'exhibited shortest harvesting span (38.10 days) followed by $\mathrm{T}_{17}$ 'Pashighat-7' as well as $\mathrm{T}_{19}$ 'Pachora Local' (42 days) and longest harvest duration was found in the genotype $T_{1}$ 'Konkan kirti' (57.50 days) followed by $\mathrm{T}_{6}$ 'Pant- $\mathrm{C}_{3}$ ' (55 days). The harvesting duration ranged from 38.10 to 57 days with mean value of 47.55 days. The treatment $T_{1}$ 'Konkan kirti' was significantly superior over other treatments except $T_{2}, T_{3}, T_{6}$ and $T_{9}$ which were statistically at par.

The variation of the harvest span in different varieties may be due to the difference in Initiation of flowering, $50 \%$ flowering and number of fruit per plant, moderately GCV of genotypes and less effect of environmental factors. Similar variation in relation to harvesting span was observed by Modak (1989), Madhu Sharma et al., (2009) and Sharma et al., (2010).

\section{Number of picking per plant}

Number of picking is also an important yield attributing character. It also indicates the longevity or harvesting duration.

The highest number of pickings per plant was observed in the genotype $\mathrm{T}_{6}$ 'Pant- $\mathrm{C}_{3}$ ' (4.95) followed by $\mathrm{T}_{5}$ 'Jayanti' (4.85) and lowest was recorded in the genotype $\mathrm{T}_{19}$ 'Pachora Local' (3.00) followed by $\mathrm{T}_{15}$ 'Pashighat-2' (3.25) and that ranged from 3.00 to 4.95 with mean value of (3.97).

The variation mostly influenced by days to 50 $\%$ flowering, moderately effected by number of fruit per plant and less effected by climatic conditions. Similar results were also reported by Manju and Sreelathakumary (2002), Sharma et al., (2010).

\section{Average fruit weight (g)}

Fruit weight of chilli ranged from (1.65 g) to $(6.01 \mathrm{~g})$ with mean value $(3.83 \mathrm{~g})$. The heaviest fruits were observed in the genotype $\mathrm{T}_{18}$ 'Karvir Local' (6.01 g) and followed by $\mathrm{T}_{4}$ 'Arka Supriya' (4.56 g) and lightest in $\mathrm{T}_{17}$ 'Pashigat-7' (1.65 g) followed by $\mathrm{T}_{1}$ 'Konkan kirti' (2.45 g).

The treatment $\mathrm{T}_{18}$ 'Karvir Local' was significantly superior as compared to other treatments.

The variation of the fruit weight may be due to direct effect of genetic makeup of genotypes and indirectly affected by environment factors. Amit et al., (2014) also reported significant variation in fruit weight. 
Int.J.Curr.Microbiol.App.Sci (2017) 6(9): 3140-3148

Fig.1 Various chilli genotypes of fruit length

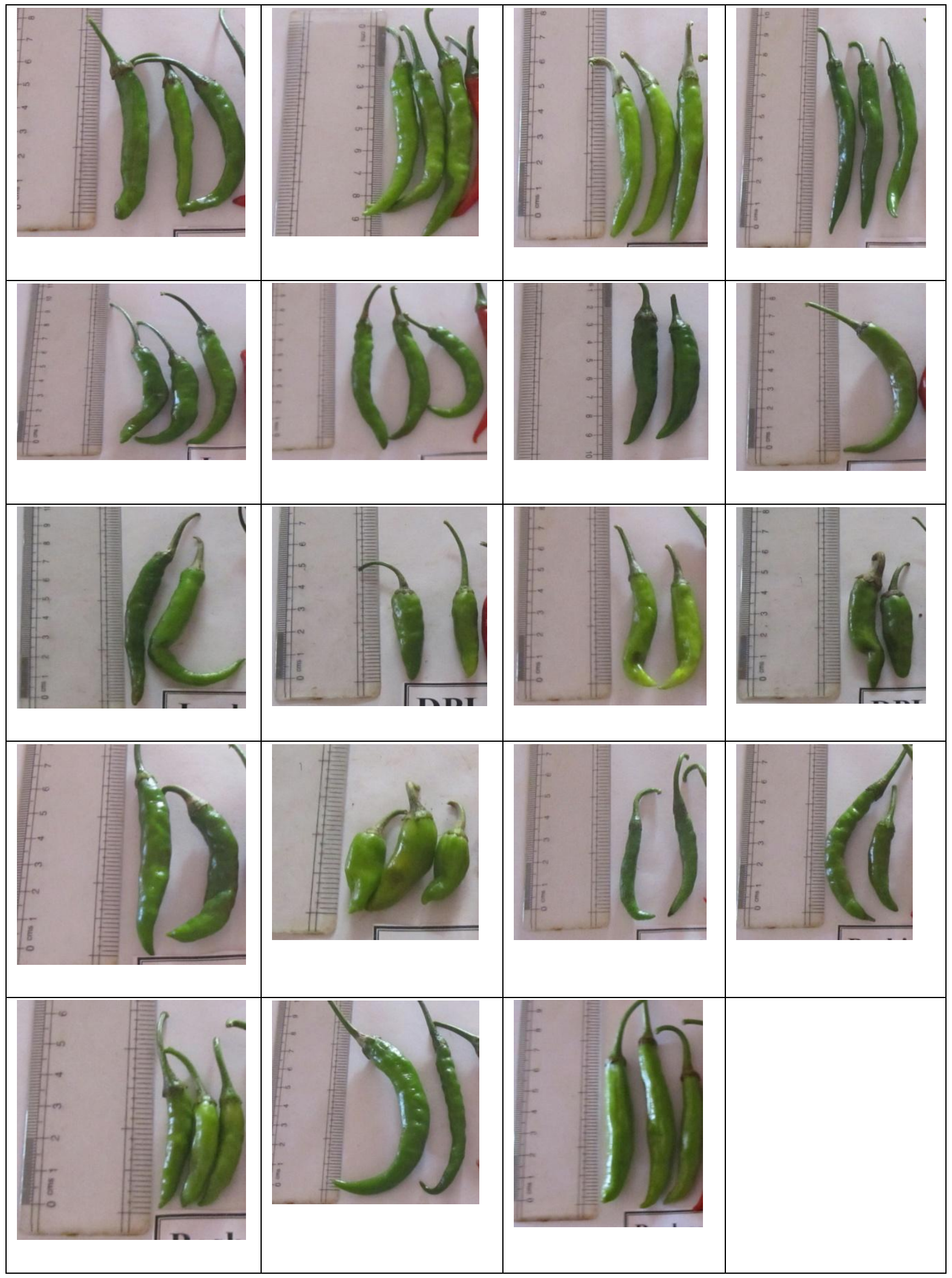


Table.1 Mean values of different yield and yield attributing traits of chilli gemotypes in coastal Maharashtra

\begin{tabular}{|c|c|c|c|c|c|c|c|c|c|c|}
\hline Treatments & $\begin{array}{l}\text { Fruit } \\
\text { length } \\
(\mathrm{cm})\end{array}$ & $\begin{array}{l}\text { Fruit } \\
\text { diamet } \\
\text { er }(\mathrm{cm})\end{array}$ & $\begin{array}{l}\text { Days to } \\
\text { first } \\
\text { harvest }\end{array}$ & $\begin{array}{l}\text { Days to } \\
\text { last } \\
\text { harvest }\end{array}$ & $\begin{array}{l}\text { Harvestig } \\
\text { Span }\end{array}$ & $\begin{array}{l}\text { Number of } \\
\text { pickings } \\
\text { per plant }\end{array}$ & $\begin{array}{l}\text { Green fruit } \\
\text { weight }(\mathrm{g})\end{array}$ & $\begin{array}{l}\text { Number } \\
\text { of fruits } \\
\text { per plant }\end{array}$ & $\begin{array}{l}\text { Green fruit } \\
\text { yield per } \\
\text { plant }(\mathrm{g})\end{array}$ & $\begin{array}{l}\text { Green } \\
\text { fruit } \\
\text { yield } \mathrm{t} / \mathrm{ha}\end{array}$ \\
\hline $\begin{array}{l}\mathrm{T}_{1}-\text { Konkan } \\
\text { Kirti }\end{array}$ & 8.42 & 0.79 & 88.50 & 146.00 & 57.50 & 4.75 & 2.45 & 173.00 & 423.85 & 15.77 \\
\hline $\mathrm{T}_{2}-\mathrm{LCA}-206$ & 10.38 & 0.73 & 80.00 & 135.20 & 52.50 & 4.00 & 3.78 & 141.00 & 461.50 & 17.13 \\
\hline $\mathrm{T}_{3}-\mathrm{LCA}-334$ & 6.94 & 0.93 & 78.60 & 128.40 & 52.50 & 4.50 & 3.98 & 156.70 & 531.43 & 19.61 \\
\hline $\begin{array}{l}\mathrm{T}_{4}-\text { Arka } \\
\text { Supriya }\end{array}$ & 8.17 & 0.95 & 81.50 & 129.20 & 47.50 & 4.25 & 4.56 & 111.50 & 409.64 & 15.14 \\
\hline $\mathrm{T}_{5}$ - Jayanti & 9.88 & 0.82 & 79.60 & 122.10 & 42.50 & 4.85 & 3.39 & 155.50 & 517.81 & 16.03 \\
\hline $\mathrm{T}_{6}$ - Pant- $\mathrm{C}_{3}$ & 8.88 & 0.81 & 92.50 & 136.50 & 55.00 & 4.95 & 3.80 & 151.40 & 555.63 & 19.72 \\
\hline $\mathrm{T}_{7}-\mathrm{ACSS}-9818$ & 9.55 & 0.86 & 87.50 & 127.70 & 47.50 & 4.85 & 3.65 & 133.30 & 411.22 & 15.26 \\
\hline $\mathrm{T}_{8}$ - Phule Sai & 8.54 & 0.78 & 89.50 & 134.00 & 46.00 & 3.50 & 4.19 & 32.30 & 159.94 & 5.87 \\
\hline $\mathrm{T}_{9^{-}}$Pusa Jwala & 9.23 & 0.75 & 89.50 & 140.00 & 52.50 & 4.25 & 2.88 & 127.00 & 492.76 & 18.24 \\
\hline $\mathrm{T}_{10}-\mathrm{DPL}_{-} \mathrm{C}_{1}$ & 5.91 & 0.95 & 81.50 & 129.00 & 47.50 & 4.50 & 2.87 & 98.50 & 515.15 & 17.42 \\
\hline $\mathrm{T}_{11}-\mathrm{DPL}-\mathrm{C}_{2}$ & 7.17 & 0.85 & 78.90 & 127.60 & 47.50 & 4.50 & 3.56 & 122.00 & 429.44 & 17.15 \\
\hline $\mathrm{T}_{12}-\mathrm{DPL}_{-} \mathrm{C}_{4}$ & 5.80 & 0.85 & 84.50 & 126.50 & 42.50 & 4.50 & 3.37 & 106.00 & 419.17 & 15.00 \\
\hline $\mathrm{T}_{13}-\mathrm{DPL}_{-} \mathrm{C}_{5}$ & 6.30 & 0.93 & 85.50 & 132.25 & 47.50 & 4.00 & 3.17 & 95.00 & 400.00 & 11.05 \\
\hline $\mathrm{T}_{14}$ - Pashighat-1 & 5.03 & 1.00 & 78.50 & 124.00 & 47.50 & 3.50 & 3.70 & 41.50 & 161.85 & 6.27 \\
\hline $\mathrm{T}_{15}$ - Pashighat-2 & 9.01 & 0.66 & 79.50 & 115.90 & 38.00 & 3.25 & 2.66 & 49.50 & 118.30 & 4.50 \\
\hline $\mathrm{T}_{16^{-}}$Pashighat-5 & 6.27 & 0.89 & 80.50 & 122.90 & 44.00 & 3.75 & 3.20 & 39.70 & 139.58 & 5.18 \\
\hline $\mathrm{T}_{17}$ - Pashighat-7 & 4.36 & 0.83 & 116.0 & 166.00 & 42.00 & 3.75 & 1.65 & 38.90 & 126.00 & 2.72 \\
\hline $\begin{array}{l}\mathrm{T}_{18}-\text { Karvir } \\
\text { Local }\end{array}$ & 12.40 & 0.95 & 74.50 & 122.10 & 47.50 & 3.50 & 6.05 & 77.00 & 462.77 & 17.13 \\
\hline $\begin{array}{l}\mathrm{T}_{19}-\text { Pachora } \\
\text { Local-1 }\end{array}$ & 8.45 & 0.89 & 109.50 & 162.50 & 42.00 & 3.00 & 4.10 & 53.78 & 188.71 & 9.33 \\
\hline Mean & & 0.85 & 86.13 & 133.04 & 47.34 & 4.11 & 3.52 & 100.18 & 364.46 & 13.88 \\
\hline Range & $\begin{array}{l}12.40 \\
-4.36\end{array}$ & $\begin{array}{l}1.00- \\
0.66\end{array}$ & $\begin{array}{l}74.50- \\
116\end{array}$ & $\begin{array}{l}115-90- \\
166.00\end{array}$ & $51.0-58.50$ & $4.95-3.00$ & $1.65-6.05$ & $\begin{array}{l}32.30- \\
173\end{array}$ & $\begin{array}{l}118.30- \\
555.63\end{array}$ & $\begin{array}{l}2.72- \\
19.70\end{array}$ \\
\hline S.E \pm & 0.163 & 0.088 & 0.532 & 3.428 & 2.760 & 0.352 & 0.069 & 9.396 & 22.963 & 0.099 \\
\hline $\mathrm{CD}$ at $(5 \%)$ & 0.475 & 0.029 & 1.582 & 10.186 & 8.202 & 1.046 & 0.207 & 27.919 & 68.227 & 0.295 \\
\hline
\end{tabular}


Table.2 Incidence of leaf curl and white fly of various chilli genotypes in coastal Maharashtra

\begin{tabular}{|c|c|c|}
\hline Treatments & Incidence of Leaf curl/plant & Incidence of White fly nymphs/leaf \\
\hline $\mathrm{T}_{1}-$ Konkan Kirti & 9.70 & 0.60 \\
\hline $\mathrm{T}_{2}-\mathrm{LCA}-206$ & 9.61 & 0.72 \\
\hline $\mathrm{T}_{3}-\mathrm{LCA}-334$ & 6.11 & 0.42 \\
\hline $\mathrm{T}_{4}-$ Arka Supriya & 11.37 & 0.70 \\
\hline $\mathrm{T}_{5^{-}}$Jayanti & 8.49 & 0.62 \\
\hline $\mathrm{T}_{6}-$ Pant- $\mathrm{C}_{3}$ & 5.39 & 0.35 \\
\hline $\mathrm{T}_{7}-\mathrm{ACSS}-9818$ & 8.37 & 0.80 \\
\hline $\mathrm{T}_{8}$ - Phule Sai & 12.65 & 1.00 \\
\hline $\mathrm{T}_{9}$ - Pusa Jwala & 7.04 & 0.48 \\
\hline $\mathrm{T}_{10^{-}} \mathrm{DPL}_{-} \mathrm{C}_{1}$ & 8.42 & 0.60 \\
\hline $\mathrm{T}_{11}-\mathrm{DPL}-\mathrm{C}_{2}$ & 9.32 & 0.66 \\
\hline $\mathrm{T}_{12}-\mathrm{DPL}-\mathrm{C}_{4}$ & 12.33 & 0.86 \\
\hline $\mathrm{T}_{13}-\mathrm{DPL}_{-} \mathrm{C}_{5}$ & 13.43 & 1.12 \\
\hline $\mathrm{T}_{14}$ - Pashighat-1 & 14.67 & 1.20 \\
\hline $\mathrm{T}_{15}$ - Pashighat-2 & 11.87 & 1.28 \\
\hline $\mathrm{T}_{16^{-}}$Pashighat-5 & 15.96 & 1.30 \\
\hline $\mathrm{T}_{17-}$ Pashighat-7 & 18.90 & 1.38 \\
\hline $\mathrm{T}_{18}-$ Karvir Local & 8.62 & 0.58 \\
\hline $\mathrm{T}_{19}$ - Pachora Local-1 & 14.72 & 1.16 \\
\hline Mean & $5.39-18.90$ & $0.35-1.38$ \\
\hline Range & 10.38 & 0.83 \\
\hline
\end{tabular}

\section{Number of fruits per plant}

Number of fruits per plant is one of the most important yield attributing character.

The number of fruits observed in present investigation in some genotypes can be regarded as appreciably high and therefore, offer a good scope for selection of promising genotypes for this character.

The highest number of fruit per plant (173) was observed in the genotype $\mathrm{T}_{1}$ 'Konkan kirti' followed by $\mathrm{T}_{3}$ 'LCA-336' (156.70) and $\mathrm{T}_{5}$ 'Jayanti' (155.50) while least in the genotype $\mathrm{T}_{8}$ 'Phule Sai' (32.30) followed by $\mathrm{T}_{17}$ 'Pashighat-7' (38.90) and $\mathrm{T}_{16}$ 'Pashighat5' (39.90). The average number of fruits per plant ranged from (32.30) to (173.00) with mean value (102.65). The treatment $T_{1}$ 'Konkan kirti' was significantly superior to other treatments except $T_{3}, T_{5}$ and $T_{6}$ which were statistically at par.

The variation in the number of fruits per plant among different genotypes might be due to fruit set percentage reported by Todankar Chaitali (2014), moderately by GCV and less effect of environment. Similar variation in above character was also reported by Sharma et al., (2010), Amit et al., (2014) and Ajjapplavana and Channa goudra (2009).

\section{Fruit yield per plant (g)}

The maximum fruit yield per plant was observed in the genotype $\mathrm{T}_{6}$ 'Pant- $\mathrm{C}_{3}$ ' (555.63 $\mathrm{g}$ ), followed by $\mathrm{T}_{3}$ 'LCA-334' (531.43 g) while minimum was observed in the genotype $\mathrm{T}_{15}$ 'Pashighat-2' (118.30 g) followed by $\mathrm{T}_{17}$ 'Pashighat-7' (126.00 g). The fruit yield per plant ranged from $(118.30 \mathrm{~g})$ to $(555.63 \mathrm{~g})$ 
with mean value $(336.96 \mathrm{~g})$. The treatment $\mathrm{T}_{6}$ 'Pant- $\mathrm{C}_{3}$ ' was significantly superior over other treatments except $T_{3}, T_{5}, T_{9}, T_{10}$ and $T_{18}$ which were statistically at par (Table 2 ).

The difference in fruit yield per plant may be due to fruit set percentage (Chaitali, 2014) and fruit length. The diameter and fruit weight showed highly positive direct effect on fruit yield per plant.

Similar results were also recorded by Sharma et al., (2010), Chattopadhyay et al., (2011), Vijaya et al., (2014) and Ukkud et al., (2007).

\section{Fruit yield t/ha}

The fruit yield per hectare varied from 2.72 t/ha to $19.72 \mathrm{t} / \mathrm{ha}$ and average yield was noticed $11.22 \mathrm{t} / \mathrm{ha}$. Highest fruit yield was recorded in genotype $\mathrm{T}_{6}$ Pant- $_{3}$ (19.72 t/ha) followed by $\mathrm{T}_{3}$ 'LCA-334' (19.61 t/ha) and minimum was observed in the genotype $T_{17}$ 'Pashighat-7' (2.72t/ha) followed by $\mathrm{T}_{15}$ 'Pashighat-2' (4.50 t/ha).

The treatment $\mathrm{T}_{6}$ 'Pant- $\mathrm{C}_{3}$ ' was significantly superior as compared to other treatments.

Variation in fruit yield per hectare might be due to number of fruits per plant, fruit length and fruit weight. Similar results were reported by Chattopadhyay (2011), Sharma et al., (2010). Indirect effect on yield by number of branches per plant and plant spread were reported by Tembhurne et al., (2008).

\section{Effect of disease and pest Incidence on yield of chilli genotypes}

\section{Incidence of Leaf curl/plant (\%)}

Maximum leaf curl disease incidence was observed in the genotype $\mathrm{T}_{17}$ (Pashighat-7) $(18.90 \%)$ followed by $\mathrm{T}_{16}(15.96 \%)$ and minimum in the genotype $\mathrm{T}_{6}$ 'Pant- $\mathrm{C}_{3}$ ' $(5.3 \%)$ followed by $\mathrm{T}_{3}$ 'LCA-334' (6.11\%). Similar observations were reported by Manju and Sreelathakumary (2002).

\section{Incidence of white fly/leaf (\%)}

Maximum white fly incidence was recorded in the genotype $\mathrm{T}_{17}$ 'Pashighat-7' (1.38\%) followed by $\mathrm{T}_{16}$ 'Pashighat-5' $(1.30 \%)$ and minimum in the genotype $\mathrm{T}_{6}$ 'Pant- $\mathrm{C}_{3}$ ' $(0.35$ $\%$ ) followed by $\mathrm{T}_{9}$ 'Pusa Jwala' $(0.49 \%)$.

The similar results are in conformity with those of Sreelathakumary and Rajamony (2004).

Based on the results it can be inferred that the chilli genotypes viz., Pant-C 3 , LCA-334, Jayanti and Karvir Local exhibited superior genotypes and have high yield potential, early genotypes and incidence of pest and disease the genotypes LCA-334, Konkan Kirti, Kavrvir Local and Pant- $\mathrm{C}_{3}$ suitable for under coastal Maharastra.

\section{References}

Ajjappalavara, P.S., and Channagoudra, R.F., 2009. Studies on variability, heritability and genetic advance in chilli (Capsicum annum. L). The Asian journal of horticulture, 4 (1): 99-101.

Amit, K., Ahad, I. and Kumar, V., 2014. Genetic variability and correlation studies for growth and yield characters in chilli (Capsicum annum.L) J. Spices and Aromatic Crops., 23 (2): 170-177.

Chaithali, T., 2014. Evaluation of yard long bean genotypes (vigna unguiculata sub sp. Sesquipedalis L.) grown under Konkan agro climatic condition of Maharashtra. Thesis submitted to deportment of horticulture in Dr.b.s.k.k.v dapoli. June Unpublished.

Chattopadhyay, A.A., Sharangi, A.A., Dai, N. and Dutta, S., 2011. Diversity of genetic resources and genetic association analyses of green and dry chillies of eastern India. Chilean journal of Agricultural Research., 
71 (3).

Kavitha, J., Kuttalam, S. and Chandrasekaran, S., 2006. Evaluation of spiromesifen 240 SC against chilli mite, Polyphagotarsonemus latus. Ann. Pl. Protec. Sci., 14: 52-55.

Khan, M.A., MA Asghar, J Iqbal, A. Ahmed \& Shamsuddin ZA., 2014. Aflatoxins contamination and prevention in red chillies (Capsicum annuum L.) in Pakistan. Food Additives \& Contaminants., Part B 7 (1): 16.

Madhu Sharma., singh,Y. and Jamwal R.S, 2009. Variability studies for various metric traits in chilli. Haryana J.hartie.sci., 3 (4): 284-287.

Manju, P.R. and Sreelathakumary, I., 2002. Genetic Variability, heritability and genetic advance in hot chilli (Capsicum chinense jacq L.) Journal of tropical agriculture, 40: 4-6.

Modak, P.V., 1989. Studies on growth yield and quality of chilli (Capsicum annum L.) varieties under Konkan conditions. Thesis submitted to Dr. B.S.K.K.V vidyapeeth. Dapoli, Unpublished.

Panse, V.G. and Sukhatme, P.V., 1989. Statistical methods for agricultural workers. Indian Council of Agrcultural Research, New Delhi. 145-150.

Sharma, H.C., \& Ortiz R., 2002. Host plant resistance to insects: an eco-friendly approach for pest management and environment conservation. J Env Biol., 23: 111-135.

Sharma, V.K., Semwal, C.S. and Uniyal, S.P., 2010. Genetic variability and character association analysis in bell pepper (Capsicum annum.L.). Journal of horticulture and forestry, 2 (3): 058-065.

Shiva, K.N., Zachariah, T.J., Leela, N.K. and Mathew, P.A., 2013. Performance of paprika and paprika alike chillies (Capsicum annum L.). Journal of Spices and Aromatic Crops, 22 (2):222-227.

Sreelatha Kumary, I., and Rajamony, L., 2004. Variabity heritability and genetic advance in Chilli (Capsicum annum. L). J. Tropical Agri., 42 (1-2): 35-37.

Tembhurne, B.V., Revenappa and Kuchanur, P.H., 2008.Varietal performance genetic variability and correlation studies in chilli (Capsicum annum L.). Karnataka J. Agri. Sci., 21 (4): 541-543.

Thul, S. T., Lal, A R., Shasany, K. K., Darokar, M. P., Gupta, A. K., Gupta, M. M., Verma, R. K., Khanuja S. P. S., 2009. Estimation of phenotypic divergence in a collection of Capsicum species for yield-related traits Euphytica DOI 10.1007/10681-009-9882.

Ukkund, K.M., Madalageri, M.B., Patil, M.P., Mulage, R. and Kotikal, Y.K., 2007. Variability studies in green Chilli (Capsicum annum L.). Karnataka J. Agri. Sci., 20 (1): 102-104.

Vijaya, H.M., Gowda, A.P.M., Nehru, S.D. and Jyothi, K., 2014. Performance of chilli (Capsicum annum L.) genotype for growth and yield parameters in eastern dry zone of Karnataka. Journal of Spices and Aromatic Crops, 23 (2):250-253.

Wien, H.C., Tripp, K.E., Hernandez-Armetana, R. and Turner, A. D., 1989. Abscission of reproductive structures in pepper: causes, mechanisms and control. In: Tomato and Pepper Production in the Tropics. Proceedings of the International Symposium on Integrated Management Practices. Asian Vegetable Research and Development Centre, Shanhua, Taiwan 150-165 pp.

\section{How to cite this article:}

Yatagiri, N., R.K. Telugu, M. Shafiqurrahaman and Sanap, P.B. 2017. Evaluation of Chilli Genotypes for Yield Attributing and Incidence of Leaf Curl and White Fly Traits in Coastal Maharashtra. Int.J.Curr.Microbiol.App.Sci. 6(9): 3140-3148.

doi: https://doi.org/10.20546/ijcmas.2017.609.388 